Journal of Agriculture and Food Sciences

Volume 19 Number 1, April 2021 pp 1-17

Olurin, T.O., Dudu, O.E., Olaniyan, A.M. and Ogunmoyela, O.A.B.

\title{
EFFECT OF OPTIMIZING PROCESS VARIABLES ON THE QUALITY CHARACTERISTICS OF CASSAVA-WHEAT COMPOSITE BREAD
}

Taiwo O. Olurin ${ }^{1}$, Olayemi E. Dudu ${ }^{1,2}$, Adeola M. Olaniyan ${ }^{1}$ and Olugbenga A. B. Ogunmoyela $^{1}$

\author{
${ }^{l}$ Department of Chemical and Food Sciences, Bells University of Technology, Ota, Ogun State, \\ Nigeria. \\ ${ }^{2}$ School of Chemistry and Chemical Engineering, Harbin Institute of Technology, Harbin, \\ 150090, China. \\ Corresponding author: toolurin@bellsuniversity.edu.ng / tayeolurin@gmail.com
}

\begin{abstract}
The optimisation of bread-making process can have a positive impact in ramping up the quality characteristics of cassava-wheat bread to that of whole wheat bread. In this study, a threevariable Box-Behnken design response surface methodology was employed to investigate and optimise independent variables namely cassava flour composition, water content and proofing time in relation to response variables namely dough yield, loaf specific volume and loaf protein of cassava-wheat-composite bread. The data from the experimental design were fitted into second-order regression models and their validity and reliability were confirmed by analysis of variance. Optimal cassava flour composition, water content and proofing time were derived as; $100 \mathrm{~g} / \mathrm{kg}, 589 \mathrm{~g} / \mathrm{kg}$ and $90 \mathrm{~min}$, respectively. It was revealed that cassava flour composition had the most effect on the quality characteristics of cassava-wheat-composite bread. At constant cassava flour composition, increase in water content and proofing time had a positive effect on all the studied quality characteristics of cassava-wheat composite bread. Increase cassava flour composition regardless of proofing time and water content had a negative effect on loaf specific volume and protein. This study has provided bread-making conditions which can be utilised in enhancing the consumer acceptability of cassava-wheat composite bread.
\end{abstract}

Keywords: Casava-wheat composite bread, Bread-making process variables, Optimisation, Bread characteristics, Nutrition.

https://dx.doi.org/10.4314/jafs.v19i1.1

\section{INTRODUCTION}

Bread is a major source of nutrition to mankind and a vital vehicle in achieving global food security. Wheat flour is undoubtedly the benchmark flour for the production of leavened pan

Journal of the Faculty of Agriculture and Veterinary Medicine, Imo State University Owerri website: www ajol.info; Attribution:Non- commercial CC BY-NC 
Journal of Agriculture and Food Sciences

Volume 19 Number 1, April 2021 pp 1-17 bread due to its unique gluten fraction which produces viscoelastic bread with exceptional sensory appeal. However, the high price of wheat in the global market, as well as the high import and processing costs incurred by countries where it is not domicile hampers the food security potentials of wheat-based leavened pan bread in these countries. Thus, the need to improve the utilisation of indigenous-potential substitutes to wheat for the production of bakery flours is pertinent at this time.

Cassava (Manihot esculenta Crantz) is a root shrub which thrives in tropical and reacclimatises well as constitutes a bulk of starch (800-900 g/kg dry basis), thus making it a viable candidate in the production of bakery flour(Ekunseitan et al., 2016; El-Sharkawy, 2014). Consequently, highquality cassava flour possesses noteworthy physicochemical and functional attributes which have been exploited in the production of baked products, steamed dough, weaning foods and pastalike products (Aniedu \& Omodamiro, 2012; Pérez \& Pérez, 2009; Steenkamp \& McCrindle, 2014). However, cassava flour has an inferior baking performance compared to wheat flour in terms of production of leavened pan bread. This is evident by cassava flour's innate gluten-free nature, poor protein quality (low protein content and deficiency in structural amino acids) and low amylase activity (Abass et al., 2018; Chisenga, Workneh, Bultosa \& Alimi, 2019; Mejiaaguero, Galeno, Hernandezhernandez, Matehus \& Tovar, 2012).

As a cheaper alternative to wheat flour as well as ramping up its bakery utilisation, cassava flour has successfully been blended with wheat flour for the production of leavened pan bread (Aristizábal, García \& Ospina, 2017; Jensen, Skibsted, Kidmose \& Thybo, 2015; Okoli, Efiuvwevwere \& Eruteya, 2020; Sampson, 2020). These aforementioned studies revealed that cassava-wheat composite flour containing a maximum of $200 \mathrm{~g} / \mathrm{kg}$ cassava flour substitution can produce consumer acceptable leavened pan bread comparable with that of wheat flour bread. Moreover, consumers are willing to pay more due to their positive perception of the healthrelated benefits and sensory quality of the product (Owusu, Owusu-Sekyere, Donkor, Darkwaah \& Adomako-Boateng, 2017). Thus, there is a need to enhance the quality of cassava-wheat bread through its bread-making process.

Process variables such as cassava flour composition, water content, baking temperature and time, as well as proofing temperature and time are critical to bread-making process. Shittu, Raji and Sanni (2007) investigated the combined effect of baking time and temperature on physical

Journal of the Faculty of Agriculture and Veterinary Medicine, Imo State University Owerri website: www ajol.info; Attribution:Non- commercial CC BY-NC 
Journal of Agriculture and Food Sciences

Volume 19 Number 1, April 2021 pp 1-17 characteristics of cassava-wheat composite bread using a central composite rotatable experimental design. It is important to mention that there is limited information on the combined effect of other bread-making process variables on the quality characteristics of cassava-wheat composite bread.

Therefore, in this study, response surface methodology was used to study and optimise some important bread-making process variables in relation to quality characteristics of cassava-wheat composite bread. The combined effects of process variables namely cassava flour composition, water content and proofing time on dough yield, loaf specific volume and loaf protein of cassava-wheat-composite bread were studied. Optimal process conditions were derived.

\section{MATERIALS AND METHOD}

\section{Experimental materials}

Commercial cassava flour was sourced from Niji foods Ltd. Oyo, Nigeria. Commercial wheat flour (Golden Penny), sugar (Dangote), fat (Toppa), table salt, improver (Beta- baker) and instant yeast (Angel) were purchased from a local supermarket in Ota, Nigeria.

\section{Dough preparation}

A straight dough method was used in the preparation of different cassava-wheat composite doughs. It is important to mention that cassava flour and water compositions, as well as proofing time conditions used in the preparation of different cassava-wheat composite doughs, were based on the experimental design discussed in section 2.7. The overall dough formulation was as follows: cassava-wheat composite flour $(700 \mathrm{~g})$, sugar $(70 \mathrm{~g})$, salt $(7 \mathrm{~g})$, yeast $(7 \mathrm{~g})$, improver $(0.14 \mathrm{~g})$ and fat $(7 \mathrm{~g})$. Dough was produced by dry-mixing all dry ingredients (cassava flour, wheat flour, sugar, salt, yeast, and improver) until properly homogenised. Then, wet ingredients (water and fat) were mixed with the dry ingredients. Resulting cassava-wheat flour doughs were kneaded, shaped, placed in lightly greased pans and then proofed at $38^{\circ} \mathrm{Cand} 800 \mathrm{~g} / \mathrm{kg}$ relative humidity in a proofing cabinet (MIWE, D-97450, Michael Wenz, Germany) for appropriate proofing times.

Journal of the Faculty of Agriculture and Veterinary Medicine, Imo State University Owerri website: www ajol.info; Attribution:Non- commercial CC BY-NC 
Journal of Agriculture and Food Sciences

Volume 19 Number 1, April 2021 pp 1-17

\section{Dough yield efficiency}

Cassava-wheat composite dough yield efficiency was determined according to the calculation described by Movahed, Rooshenas and Ahmadichenarbon (2011)which is as follows:

Dough yield efficiency $(\%)=\left(\mathrm{W}_{2} / \mathrm{W}_{1}\right) \times 100$

where, $\mathrm{W}_{1}$ is cassava wheat composite flour weight and $\mathrm{W}_{2}$ is dough weight (flour and all ingredients) after proofing.

\section{Bread preparation}

The different cassava-wheat composite doughs derived from the straight dough method described in section 2.2 were baked at $180{ }^{\circ} \mathrm{C}$ for 30 mins in an electric oven (MIWE, CO 11206, Michael Wenz, Germany). The baked cassava-wheat composite bread loaves were depanned, cooled to ambient temperature and then subjected to analysis.

\section{Loaf protein determination}

The different cassava-wheat composite breads were analysed for protein using the AOAC, 1995, 960.52 method.

\section{Loaf specific volume determination}

The loaf weight and volume of the cassava flour composite breads were determined using a laser detection instrument (TexVol, BVM-L370, TexVol Instruments, Sweden). Specific volume was calculated as follows:

Specific volume $(\mathrm{mL} / \mathrm{g})=$ Loaf weight $/$ loaf volume

\section{Experimental design and process optimisation}

Preliminary studies were done in establishing cassava flour composition, water content and proofing time conditions which produced cassava-wheat composite bread with desirable nutritional and quality characteristics. Consequently, a cassava flour composition range (100 to $500 \mathrm{~g} / \mathrm{kg}$ ), water content (500 to $600 \mathrm{~g} / \mathrm{kg}$ ) and proofing time range (60 to $90 \mathrm{~min}$ ) were derived. These conditions were fitted into a three-variable Box-Behnken design response surface methodology with cassava flour composition, water content and proofing time as independent variables and dough yield efficiency, loaf specific volume and loaf protein as response variables

Journal of the Faculty of Agriculture and Veterinary Medicine, Imo State University Owerri website: www ajol.info; Attribution:Non- commercial CC BY-NC 
Journal of Agriculture and Food Sciences

Volume 19 Number 1, April 2021 pp 1-17 using design expert software (version 10, Stat Ease Inc., USA). Minimum, mean and maximum data imputed into the design were coded as $-1,0$, and 1 . Experimental runs were generated by the software which as shown in Table 1. Data generated from the Box-Behnken design were fitted into a modified second-order quadratic regression model presented by Granato and de Araújo Calado (2014) which is as follows

$$
\mathrm{Y}=\beta_{0}+\beta_{1} \mathrm{C}+\beta_{2} \mathrm{~W}+\beta_{3} \mathrm{P}+\beta_{11} \mathrm{CW}+\beta_{12} \mathrm{CP}+\beta_{13} \mathrm{WP}+\beta_{21} \mathrm{C}^{2}+\beta_{22} \mathrm{~W}^{2}+(3)
$$

where $Y$ is the response function, $\beta_{0}$ which is the intercept, linear coefficients $\beta_{1}, \beta_{2}$ and $\beta_{3}$, interactive coefficients $\beta_{11}, \beta_{12}$ and $\beta_{13}$ and quadratic coefficients $\beta_{21}, \beta_{22}$ and $\beta_{23}, C$ is cassava flour composition, $\mathrm{W}$ is water content and $\mathrm{P}$ is proofing time. Predictive models for each response were generated by the software and the validity and reliability of the models were determined by analysis of variance (ANOVA). The predictive models were used to generate the response surface plots shown in Figs. 1-3. The independent variables were optimised using a numerical technique which entailed taking decisions to keep the independent variables within range, and to maximize all response variables These decisions were processed by a desirability function(Myers \& Montgomery, 2002) which is as follows:

$$
D(x)=\left(d_{1} \times d_{2} \times \ldots . . d_{n}\right) 1 / n
$$

where $D(x)$ is desirability function, $d_{1}, d_{2}$ to $d_{n}$ are the desirability indices for each dependent variable and $\mathrm{n}$ is the number of considered dependent variables. Based on the decisions made, the set of optimal values with the highest desirability factor (having a maximum value of 1) was chosen.

\section{Statistical analysis}

Triplicate data from all the analysis were analysed using the Statistical Package for the Social Sciences v. 26.0 (SPSS, USA). Means were compared with aid of a one-way analysis of variance (ANOVA) using a significance level of $\mathrm{P}<0.05$. Duncan's post hoc test was used in describing and characterising the differences among the datasets.

Journal of the Faculty of Agriculture and Veterinary Medicine, Imo State University Owerri website: www ajol.info; Attribution:Non- commercial CC BY-NC 
Journal of Agriculture and Food Sciences

Volume 19 Number 1, April 2021 pp 1-17

RESULTS AND DISCUSSION
Olurin, T.O., Dudu, O.E., Olaniyan, A.M. and Ogunmoyela, O.A.B.

\section{Model description}

A three-variable Box-Behnken experimental design consisting of independent variables (cassava flour composition, water content and proofing time) and response variables (dough yield efficiency, loaf specific volume and loaf protein) was developed and the results of the different experimental runs are shown in Table 1. In describing the relationship between the independent variables and response variables, the results from the Box-Behnken design for each the response variable were fitted by second order polynomial (quadratic) regression models which are as follows:

$$
\begin{aligned}
\mathrm{Y}_{1}= & 154.29+0.27 \mathrm{C}+1.96 \mathrm{~W}-1.16 \mathrm{P}+-2.76 \mathrm{E}-014 \mathrm{CW}-4.11 \mathrm{CP}+0.36 \mathrm{WP}-0.98 \mathrm{C}^{2}-1.16 \mathrm{~W}^{2}+ \\
& 0.80 \mathrm{P}^{2} \\
\mathrm{Y}_{2}= & 3.55-1.20 \mathrm{C}+0.03 \mathrm{~W}-0.03 \mathrm{P}-0.03 \mathrm{CW}-0.31 \mathrm{CP}-0.20 \mathrm{WP}-0.14 \mathrm{C}^{2}-0.05 \mathrm{~W}^{2}-0.14 \mathrm{P}^{2} \\
\mathrm{Y}_{3}= & 96.70-26.60 \mathrm{C}+3.19 \mathrm{~W}-4.21 \mathrm{P}+1.83 \mathrm{CW}-1.03 \mathrm{CP}+4.65 \mathrm{WP}+3.40 \mathrm{C}^{2}-3.28 \mathrm{~W}^{2}-0.23 \mathrm{P}
\end{aligned}
$$

where, $Y_{1}$ is dough yield efficiency, $Y_{2}$ is loaf specific volume and $Y_{3}$ is loaf protein. ANOVA was used to describe the effect of the independent variables on the response variables which is shown in Table 2. The coefficient of determination $\left(\mathrm{R}^{2}\right)$ values of the $Y_{1}, Y_{2}$ and $Y_{3}$ models were 0.93, 0.94 and0.96, indicating that the models were not able to explain $7 \%, 6 \%$ and $4 \%$ of the total variation of dough yield efficiency, loaf specific volume and loaf protein data, respectively. Probability values (P-values) of the $Y_{1}, Y_{2}$ and $Y_{3}$ models were $\mathrm{P}<0.01$. Based on the high $\mathrm{R}^{2}$ values and significant P-values, all the models were reliable and valid in serving as predictive models for the optimisation process.

\section{Dough yield efficiency versus process variables}

Dough yield efficiency plays a vital role in predicting the baking performance of flour (Movahed et al., 2011). Cassava-wheat composite dough yield efficiency ranged from $150 \%$ to $159 \%$ (Table 1). Based on the ANOVA results, linear effects of water content and proofing time, interaction effect of cassava flour composition and proofing time as well as quadratic effects of cassava flour composition and water content had significant effects $(\mathrm{p}<0.05)$ on cassava-wheat composite dough yield efficiency (Table 1). Response surface plots illustrating the effect of the process variables on cassava-wheat composite dough yield efficiency are shown in Fig. 1.From the plots, major increase in cassava-wheat composite dough yield efficiency was ensued by Journal of the Faculty of Agriculture and Veterinary Medicine, Imo State University Owerri website: www ajol.info; Attribution:Non- commercial CC BY-NC 
Journal of Agriculture and Food Sciences

Volume 19 Number 1, April 2021 pp 1-17
Olurin, T.O., Dudu, O.E., Olaniyan, A.M. and Ogunmoyela, O.A.B.

increase in water content and proofing time at constant cassava flour composition (Fig. 1c). However, other positive effects on cassava-wheat composite dough yield efficiency were observed. At constant water content, high cassava flour composition and low proofing time, as well as low cassava flour composition and high proofing time, led to increase in cassava-wheat composite dough yield efficiency (Fig. 1b). A similar increase in cassava-wheat composite dough yield efficiency was obtained at low cassava flour composition and high-water content at constant proofing time (Fig. 1a). These findings suggest that the combination of the abovementioned process conditions facilitated the incorporation and retention of as by the cassava-wheat composite dough system.

\section{Loaf specific volume versus process variables}

Specific loaf volume is a vital quality characteristic of bread which influences consumer acceptability. Cassava-wheat composite loaf specific volume ranged from 1.93 to $4.85 \mathrm{~mL} / \mathrm{g}$ (Table 1). Based on the ANOVA results, linear effect of cassava flour composition and interaction effect of cassava composition and proofing time had significant effects $(\mathrm{p}<0.05)$ on cassava-wheat composite loaf specific volume (Table 2). Response surface plots illustrating the effect of the process variables on cassava-wheat composite loaf specific volume are shown in Fig. 2. From the plots, major increase in cassava-wheat composite loaf specific volume was ensued by increase in water content and proofing time at constant cassava flour composition (Fig. 2c). Negative effects on cassava-wheat composite loaf specific volume were revealed by both increase in water content and cassava composition at constant proofing time (Fig. 2 a) as well as increase in cassava flour composition and proofing time at constant water content (Fig. 2 b). Regardless of proofing time and water content conditions, increase cassava flour composition led to significant decrease in cassava-wheat composite loaf specific volume. The latter findings are consistent with existing studies which revealed that increase in cassava flour composition led to decrease in cassava-wheat composite loaf volume or loaf specific volume(Abass et al., 2018; Ayele, Bultosa, Abera \& Astatkie, 2017). Cassava flour is deficient in structural proteins (sulphur-containing amino acids) which makes it unable to form adequate network structures that can retain gas during dough development (Abass et al., 2018). Thus, the dilution of wheat gluten by increased cassava flour substitution played a significant role in decreasing structural integrity of the composite dough during proofing and baking thereby decreasing in loaf volume. 
Journal of Agriculture and Food Sciences

Volume 19 Number 1, April 2021 pp 1-17
Olurin, T.O., Dudu, O.E., Olaniyan, A.M. and Ogunmoyela, O.A.B.

The protein content serves as an important nutritional element which enhances the overall value of bread. Cassava-wheat composite loaf protein ranged from 74.20 to $128.40 \mathrm{~g} / \mathrm{kg}$ (Table 1). Based on the ANOVA results, linear effects of cassava flour composition and proofing time had significant effects $(\mathrm{p}<0.05)$ on cassava-wheat composite loaf protein (Table 2). Response surface plots illustrating the effect of the process variables on cassava-wheat composite loaf protein are shown in Fig. 3. From the plots, major increase in on cassava-wheat composite loaf protein was ensued by increase in water content and proofing time at constant cassava flour composition (Fig. 1c). Negative effects on cassava-wheat composite loaf protein were revealed by both increase in water content and cassava composition at constant proofing time (Fig. 3 a) as well as increase in cassava flour composition and proofing time at constant water content (Fig. 3b). Regardless of proofing time and water content conditions, increase cassava flour composition led to decrease in cassava-wheat composite loaf protein. The latter finding concurs with that of Ayele et al. (2017) who also observed decrease protein content of cassava-wheat composite bread with increase in cassava flour substitution.

\section{Optimisation of process parameters}

A numerical method which entailed taking the decisions to keep independent variables (cassava flour composition, water content and proofing time) within the experimental range and to maximize all response variables (dough yield efficiency, loaf specific volume and loaf protein) was done using the design expert software. Consequently, 5 sets of results were presented by the software and the set of results with the highest desirability factor was selected. The optimal cassava flour composition, water content and proofing time conditions were $100 \mathrm{~g} / \mathrm{kg}, 589 \mathrm{~g} / \mathrm{kg}$ and $90 \mathrm{~min}$, respectively, and corresponding dough yield efficiency, loaf specific volume and loaf protein values were $157.89 \%, 4.61 \mathrm{~mL} / \mathrm{g}$ and $126 \mathrm{~g} / \mathrm{kg}$, respectively, with a desirability factor of 0.91 .

\section{CONCLUSION}

This study elucidated the linear, interaction and quadratic effects of bread-making process variables (cassava flour composition, water content and proofing time) on the quality 
Journal of Agriculture and Food Sciences

Volume 19 Number 1, April 2021 pp 1-17

Olurin, T.O., Dudu, O.E., Olaniyan, A.M. and Ogunmoyela, O.A.B.

characteristics of cassava-wheat composite bread using response surface methodology. In addition, optimal conditions for the development of cassava-wheat cassava bread with high dough yield, loaf specific volume and loaf protein were proposed. On the overall, the studied quality characteristics of cassava-wheat cassava bread were highly dependent on cassava flour composition. It was demonstrated that by increasing proofing time and water content at constant cassava flour composition improvements in all studied quality characteristics were achieved. Increase in cassava flour composition during the bread-making process had a negative effect on loaf specific volume and loaf protein of cassava-wheat-composite bread. Furthermore, this study also established that enhancement in dough yield efficiency was achieved at high cassava flour composition and proofing time at constant water content.

Journal of the Faculty of Agriculture and Veterinary Medicine, Imo State University Owerri website: www ajol.info; Attribution:Non- commercial CC BY-NC 
Journal of Agriculture and Food Sciences

Volume 19 Number 1, April 2021 pp 1-17
Olurin, T.O., Dudu, O.E., Olaniyan, A.M. and Ogunmoyela, O.A.B.

\section{REFERENCES}

Abass, A. B., Awoyale, W., Alenkhe, B., Malu, N., Asiru, B. W., Manyong, V., \& Sanginga, N. (2018). Can food technology innovation change the status of a food security crop? a review of cassava transformation into "bread" in Africa. Food Reviews International, 34(1), 87102. https://doi.org/10.1080/87559129.2016.1239207

Aniedu, C., \& Omodamiro, R. (2012). Use of Newly Bred B-Carotene Cassava in Production of Value-Added Products: Implication for Food Security in Nigeria. Global Journal of Science Frontier Research, 12(10), 10-16.

AOAC. (1995). Official Methods of Analysis (16 ed.). Virginia: Association of Official Analytical Chemists International.

Aristizábal, J., García, J. A., \& Ospina, B. (2017). Refined cassava flour in bread making: a review. Ingeniería e Investigación, 25-33. https://doi.org/10.15446/ing.investig.v37n1.57306

Ayele, H. H., Bultosa, G., Abera, T., \& Astatkie, T. (2017). Nutritional and sensory quality of wheat bread supplemented with cassava and soybean flours. Cogent Food and Agriculture, 3(1), 1331892. https://doi.org/10.1080/23311932.2017.1331892

Chisenga, S. M., Workneh, T. S., Bultosa, G., \& Alimi, B. A. (2019). Progress in research and Applications of cassava flour and starch: a review. Journal of Food Science Technology, 115. https://doi.org/10.1007/s13197-019-03814-6

Ekunseitan, O. F., Obadina, A. O., Sobukola, O. P., Omemu, A. M., Adegunwa, M. O., Kajihausa, O. E., Adebowale, A. R. A., Sanni, S. A., Sanni, L. O., \& Keith, T. (2017). Nutritional composition, functional and pasting properties of wheat, mushroom, and highquality cassava composite flour. Journal of Food Processing and Preservation, 41(5), 13150. https://doi.org/10.1111/jfpp. 13150

El-Sharkawy, M. A. (2014). Global warming: causes and impacts on agroecosystems productivity and food security with emphasis on casssava comparative advantage in the 
Journal of Agriculture and Food Sciences

Volume 19 Number 1, April 2021 pp 1-17 tropics/sub-tropics. Photosynthetica, 52(2), 161-178. https://doi.org/10.1007/s11099-0140028-7

Granato, D., \& de Araújo Calado, V. M. (2014). The use and importance of design of experiments (DOE) in process modelling in food science and technology. In: Mathematical and Statistical Methods in Food Science and Technology (pp. 1-18): John Wiley \& Sons, Ltd. https://doi.org/10.1002/9781118434635.ch01

Jensen, S., Skibsted, L. H., Kidmose, U., \& Thybo, A. K. (2015). Addition of cassava flours in bread-making: Sensory and textural evaluation. LWT - Food Science and Technology, 60(1), 292-299. https://doi.org/10.1016/j.lwt.2014.08.037

Mejiaaguero, L. E., Galeno, F., Hernandezhernandez, O., Matehus, J., \& Tovar, J. (2012). Starch determination, amylose content and susceptibility to in vitro amylolysis in flours from the roots of 25 cassava varieties. Journal of the Science of Food and Agriculture, 92(3), 673 678. https://doi.org/10.1002/jsfa.4629

Movahed, S., Rooshenas, G. H., \& Ahmadichenarbon, H. (2011). Evaluation of the effect of liquid sourdough method on dough yield, bread yield and organoleptic properties Iranian Lavash bread. World Applied Sciences Journal, 15(7), 1054-1058.

Myers, R. H., \& Montgomery, D. C. (2002). Response Surface Methodology (2nd ed.). New York: John Wiley \& Sons, Inc.

Okolo, C. L., Efiuvwevwere, B. J. O., \& Eruteya, O. C. (2020). Investigation on Microbiological, Organoleptic and Shelf Life Characteristics of Wheat-cassava Bread. Journal of Advances in Microbiology, 20(9), 87-106. https://doi.org/10.9734/jamb/2020/v20i930283

Owusu, V., Owusu-Sekyere, E., Donkor, E., Darkwaah, N. A., \& Adomako-Boateng, D. (2017). Consumer perceptions and willingness to pay for cassava-wheat composite bread in Ghana. Journal of Agribusiness in Developing and Emerging Economies, 7(2), 115-134. https://doi.org/10.1108/JADEE-11-2014-0044

Pérez, E., \& Pérez, L. (2009). Effect of the addition of cassava flour and beetroot juice on the quality of fettuccine. African Journal of Food Science, 3 (11), 352-360.

Journal of the Faculty of Agriculture and Veterinary Medicine, Imo State University Owerri website: www ajol.info; Attribution:Non- commercial CC BY-NC 
Journal of Agriculture and Food Sciences

Volume 19 Number 1, April 2021 pp 1-17

Olurin, T.O., Dudu, O.E., Olaniyan, A.M.

Sampson, G. O. (2020). Assessing Consumer Acceptability of Composite Cassava (Manihot esculenta) Bread. Food Nutrition Sciences, 11(11), 990-1002. https://doi.org/10.4236/fns.2020.1111070

Shittu, T. A., Raji, A. O., \& Sanni, L. O. (2007). Bread from composite cassava-wheat flour: I effect of baking time and temperature on some physical properties of bread loaf. Food Research International, 40(2), 280-290. https://doi.org/10.1016/j.foodres.2006.10.012

Steenkamp, V. \& McCrindle, C. M. (2014). Production, consumption and nutritional value of cassava (Manihot esculenta, Crantz) in Mozambique: an overview. Journal of Agricultural $\begin{array}{llll}\text { Biotechnology and } & \text { Sustainable } & \text { Development, }\end{array}$ https://doi.org/10.5897/JABSD2014.022

Journal of the Faculty of Agriculture and Veterinary Medicine, Imo State University Owerri website: www ajol.info; Attribution:Non- commercial CC BY-NC 
Olurin, T.O., Dudu, O.E., Olaniyan, A.M. Volume 19 Number 1, April 2021 pp 1-17 and Ogunmoyela, O.A.B.

Table 1 Box-Behnken design results of different experimental runs

\begin{tabular}{ccccccc}
\hline $\begin{array}{c}\text { Experimental } \\
\text { run }\end{array}$ & $\begin{array}{c}\text { Cassava flour } \\
\text { composition } \\
(\mathrm{g} / \mathrm{kg})\end{array}$ & $\begin{array}{c}\text { Water content } \\
(\mathrm{g} / \mathrm{kg})\end{array}$ & $\begin{array}{c}\text { Proofing time } \\
(\mathrm{min})\end{array}$ & $\begin{array}{c}\text { Dough yield } \\
\text { efficiency } \\
(\%)\end{array}$ & $\begin{array}{c}\text { Specific } \\
\text { volume } \\
(\mathrm{mL} / \mathrm{g})\end{array}$ & $\begin{array}{c}\text { Protein content } \\
(\mathrm{g} / \mathrm{kg})\end{array}$ \\
\hline 1 & 300 & 500 & 90 & $150.00 \pm 0.25^{\mathrm{d}}$ & $3.46 \pm 0.02^{\mathrm{b}}$ & $76.00 \pm 0.10^{\mathrm{e}}$ \\
2 & 300 & 600 & 60 & $157.14 \pm 0.15^{\mathrm{b}}$ & $3.64 \pm 0.05^{\mathrm{b}}$ & $\begin{array}{c}101.10 \pm 0.15^{\mathrm{c}} \\
3\end{array}$ \\
\hline & 100 & 550 & 60 & $150.00 \pm 0.10$ & $3.93 \pm 0.05^{\mathrm{b}}$ & $128.40 \pm 0.10^{\mathrm{a}}$ \\
4 & 100 & 600 & 75 & $154.29 \pm 0.12^{\mathrm{c}}$ & $4.85 \pm 0.02^{\mathrm{a}}$ & $120.90 \pm 0.11^{\mathrm{ab}}$ \\
5 & 300 & 550 & 75 & $154.29 \pm 0.10^{\mathrm{c}}$ & $3.55 \pm 0.02^{\mathrm{b}}$ & $96.70 \pm 0.25^{\mathrm{cd}}$ \\
6 & 500 & 550 & 60 & $159.29 \pm 0.10^{\mathrm{a}}$ & $2.40 \pm 0.05^{\mathrm{c}}$ & $74.40 \pm 0.15^{\mathrm{e}}$ \\
7 & 300 & 550 & 75 & $154.29 \pm 0.10^{\mathrm{c}}$ & $3.55 \pm 0.02^{\mathrm{b}}$ & $96.70 \pm 0.25^{\mathrm{cd}}$ \\
8 & 100 & 500 & 75 & $150.00 \pm 0.12^{\mathrm{d}}$ & $4.52 \pm 0.05^{\mathrm{a}}$ & $123.10 \pm 0.15^{\mathrm{ab}}$ \\
9 & 300 & 600 & 90 & $154.29 \pm 0.13^{\mathrm{c}}$ & $2.93 \pm 0.02^{\mathrm{c}}$ & $96.60 \pm 0.15^{\mathrm{cd}}$ \\
10 & 300 & 500 & 60 & $154.29 \pm 0.15^{\mathrm{c}}$ & $3.38 \pm 0.01^{\mathrm{b}}$ & $99.10 \pm 0.10^{\mathrm{c}}$ \\
11 & 300 & 550 & 75 & $154.29 \pm 0.10^{\mathrm{c}}$ & $3.55 \pm 0.02^{\mathrm{b}}$ & $96.70 \pm 0.25^{\mathrm{cd}}$ \\
12 & 100 & 550 & 90 & $157.14 \pm 0.08^{\mathrm{a}}$ & $4.73 \pm 0.05^{\mathrm{a}}$ & $127.40 \pm 0.11^{\mathrm{a}}$ \\
13 & 500 & 600 & 75 & $154.29 \pm 0.12^{\mathrm{c}}$ & $2.12 \pm 0.05^{\mathrm{d}}$ & $74.20 \pm 0.15^{\mathrm{e}}$ \\
14 & 500 & 500 & 75 & $150.00 \pm 0.12^{\mathrm{d}}$ & $1.93 \pm 0.05^{\mathrm{d}}$ & $69.10 \pm 0.10^{\mathrm{f}}$ \\
15 & 300 & 550 & 75 & $154.29 \pm 0.10^{\mathrm{c}}$ & $3.55 \pm 0.02^{\mathrm{b}}$ & $96.70 \pm 0.25^{\mathrm{cd}}$ \\
16 & 500 & 550 & 90 & $150.00 \pm 0.12^{\mathrm{d}}$ & $1.98 \pm 0.05^{\mathrm{d}}$ & $69.30 \pm 0.12^{\mathrm{f}}$ \\
17 & 300 & 550 & 75 & $154.29 \pm 0.10^{\mathrm{c}}$ & $3.55 \pm 0.02^{\mathrm{b}}$ & $96.70 \pm 0.25^{\mathrm{cd}}$ \\
\hline
\end{tabular}


Journal of Agriculture and Food Sciences

Volume 19 Number 1, April 2021 pp 1-17
Olurin, T.O., Dudu, O.E., Olaniyan, A.M. and Ogunmoyela, O.A.B.

Table 2: ANOVA on the effect of response models on quality of cassava-wheat composite flour bread

\begin{tabular}{|c|c|c|c|c|c|}
\hline $\begin{array}{l}\text { Variance } \\
\text { Source }\end{array}$ & DF & & $\mathrm{Y}_{1}$ & $\mathrm{Y}_{2}$ & $\mathrm{Y}_{3}$ \\
\hline \multirow[t]{2}{*}{$\mathrm{C}$} & 1 & F-value & 1.020 & 236.150 & 323.360 \\
\hline & & $P$-value & 0.347 & $0.001^{*}$ & $0.001 *$ \\
\hline \multirow[t]{2}{*}{ W } & 1 & $F$-value & 54.650 & 0.160 & 4.640 \\
\hline & & $P$-value & $0.002 *$ & 0.703 & 0.068 \\
\hline \multirow[t]{2}{*}{$\mathrm{P}$} & 1 & F-value & 19.080 & 0.150 & 8.110 \\
\hline & & $P$-value & $0.003 *$ & 0.708 & $0.025^{*}$ \\
\hline \multirow[t]{2}{*}{$\mathrm{CW}$} & 1 & F-value & 0 & 0.098 & 0.760 \\
\hline & & $P$-value & 1.000 & 0.763 & 0.412 \\
\hline \multirow[t]{2}{*}{$\mathrm{CP}$} & 1 & F-value & 119.450 & 7.720 & 0.240 \\
\hline & & $P$-value & $0.001^{*}$ & $0.027 *$ & 0.639 \\
\hline \multirow[t]{2}{*}{ WP } & 1 & F-value & 0.900 & 3.200 & 4.940 \\
\hline & & $P$-value & 0.374 & 0.117 & 0.062 \\
\hline \multirow[t]{2}{*}{$\mathrm{C}^{2}$} & 1 & F-value & 7.190 & 1.700 & 2.780 \\
\hline & & $P$-value & $0.032 *$ & 0.234 & 0.139 \\
\hline \multirow[t]{2}{*}{$\mathrm{W}^{2}$} & 1 & $F$-value & 10.040 & 0.220 & 2.580 \\
\hline & & $P$-value & $0.026^{*}$ & 0.654 & 0.152 \\
\hline \multirow[t]{2}{*}{$\mathrm{P}^{2}$} & 1 & F-value & 4.810 & 1.750 & 0.012 \\
\hline & & $P$-value & 0.064 & 0.227 & 0.915 \\
\hline \multirow[t]{2}{*}{ Model } & 9 & F-value & 24.090 & 27.940 & 38.570 \\
\hline & & $P$-value & $0.002 *$ & $0.001 *$ & $0.001 *$ \\
\hline $\mathrm{R}^{2}$ & & & 0.929 & 0.938 & 0.955 \\
\hline
\end{tabular}

* indicate significant factors $(\mathrm{p}<0.05), \mathrm{Y} 1$ is dough yeild efficiency, $\mathrm{Y} 2$ is loaf specific volume, Y3is loaf protein, $\mathrm{C}$ represents casssava flour composition, $\mathrm{W}$ represents steam-heat temperature. $\mathrm{P}$ represents treatment time, R2 represents adjusted R2, F-value represents F-statistic and P-value represents probability value and DF represents degree of freedom.

Journal of the Faculty of Agriculture and Veterinary Medicine, Imo State University Owerri website: www ajol.info; Attribution:Non- commercial CC BY-NC 
Journal of Agriculture and Food Sciences Volume 19 Number 1, April 2021 pp 1-17
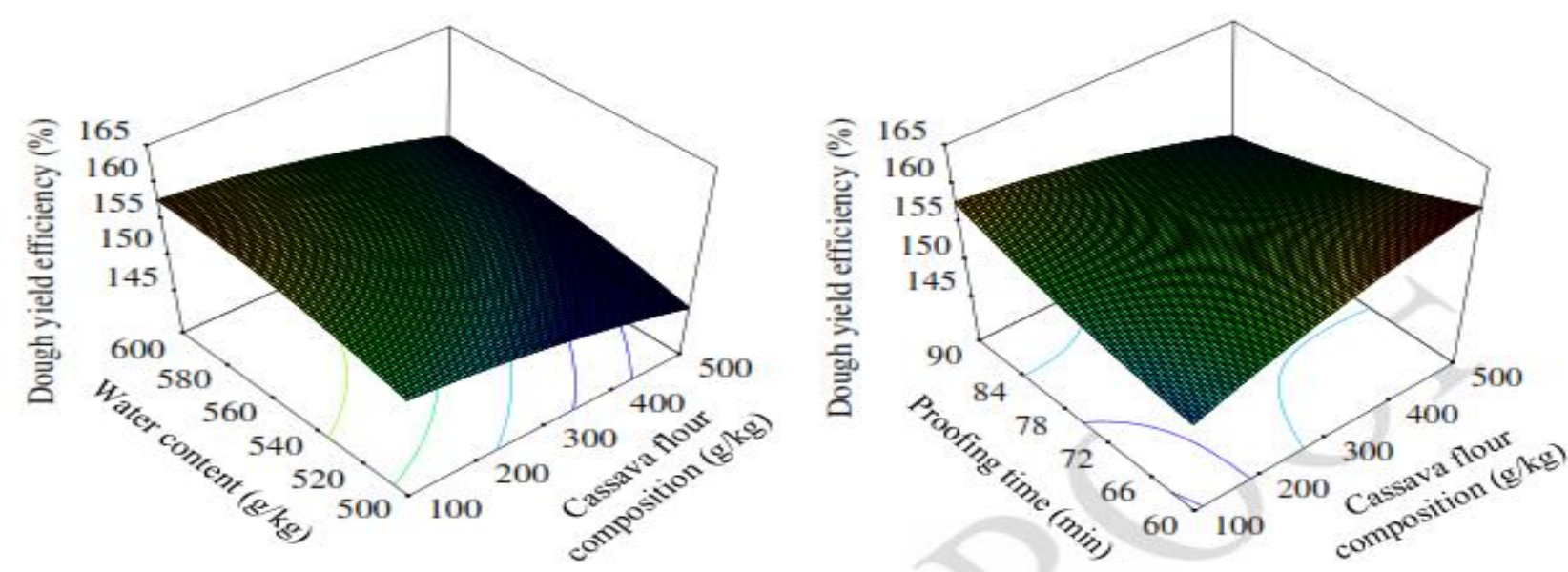

Olurin, T.O., Dudu, O.E., Olaniyan, A.M.

and Ogunmoyela, O.A.B.

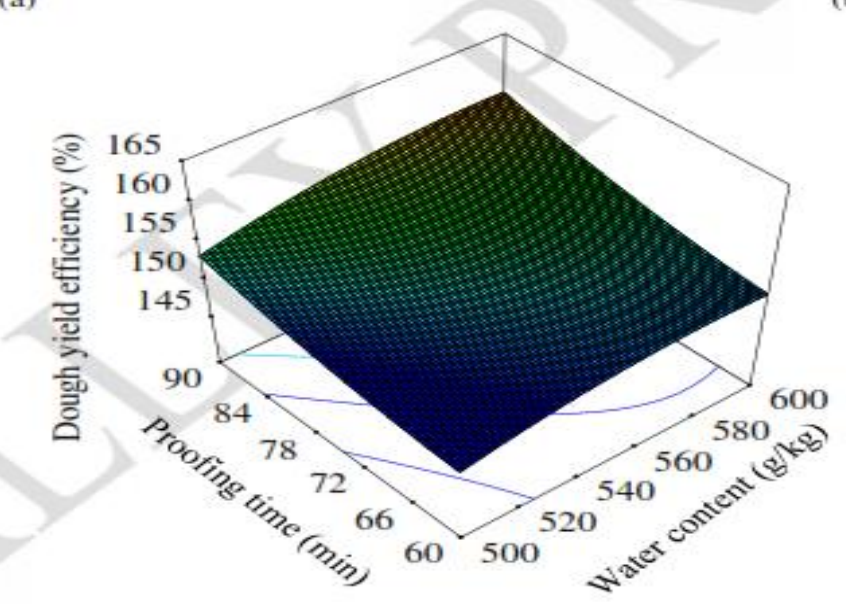

(c)

Fig. 1 Response surface plots of dough yield efficiency as a function of different experimental conditions

Journal of the Faculty of Agriculture and Veterinary Medicine, Imo State University Owerri website: www ajol.info; Attribution:Non- commercial CC BY-NC 
Journal of Agriculture and Food Sciences

Volume 19 Number 1, April 2021 pp 1-17
Olurin, T.O., Dudu, O.E., Olaniyan, A.M. and Ogunmoyela, O.A.B.

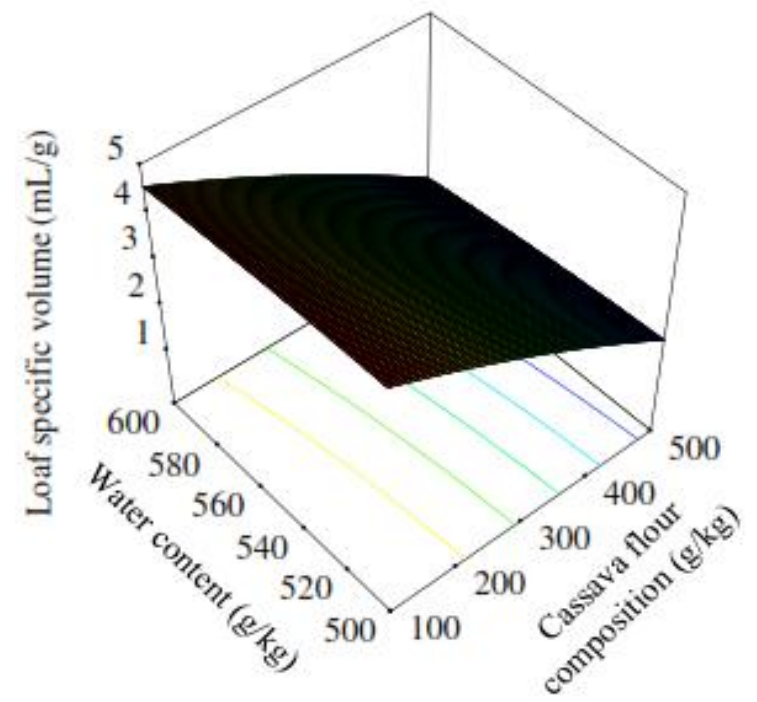

(a)

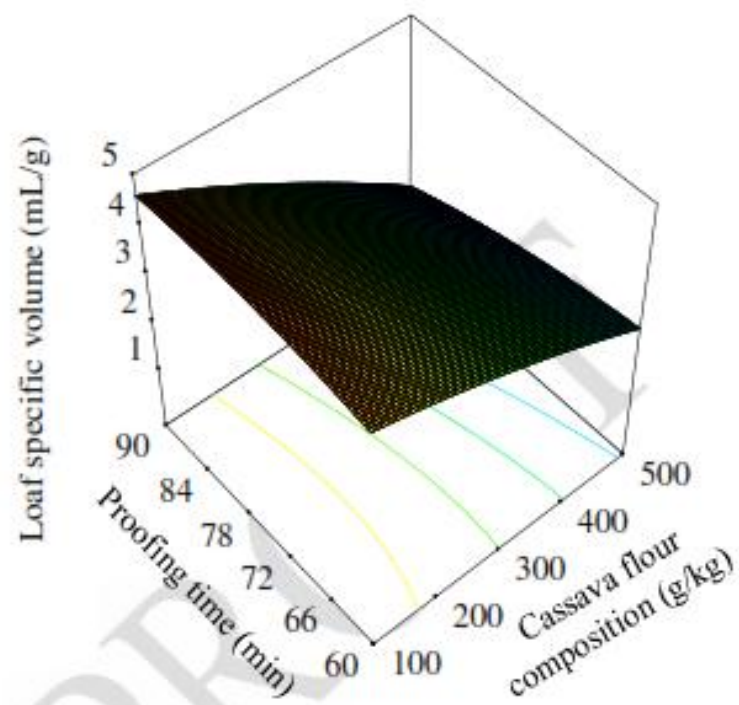

(b)

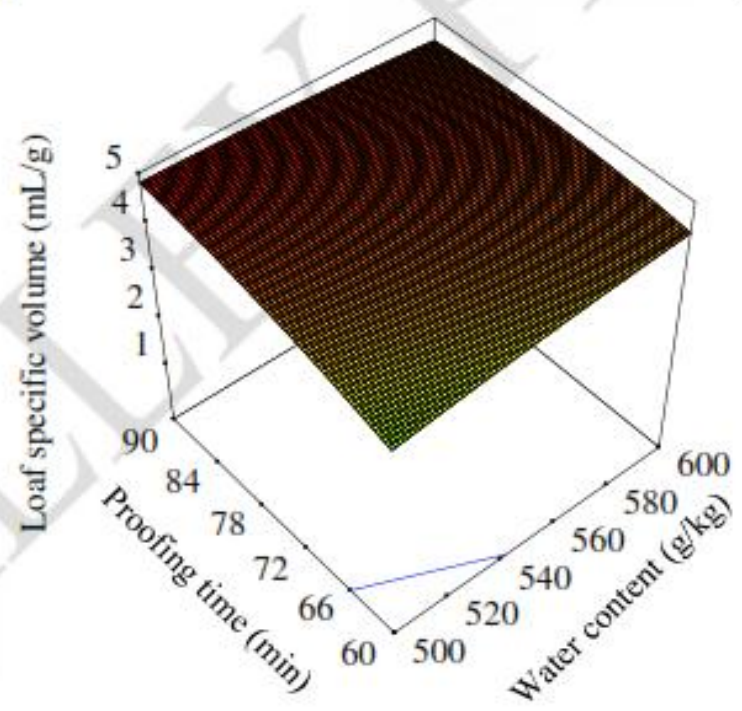

(c)

Fig. 2 Response surface plots of specific loaf volume as a function of different experimental conditions

Journal of the Faculty of Agriculture and Veterinary Medicine, Imo State University Owerri website: www ajol.info; Attribution:Non- commercial CC BY-NC 
Journal of Agriculture and Food Sciences

Volume 19 Number 1, April 2021 pp 1-17

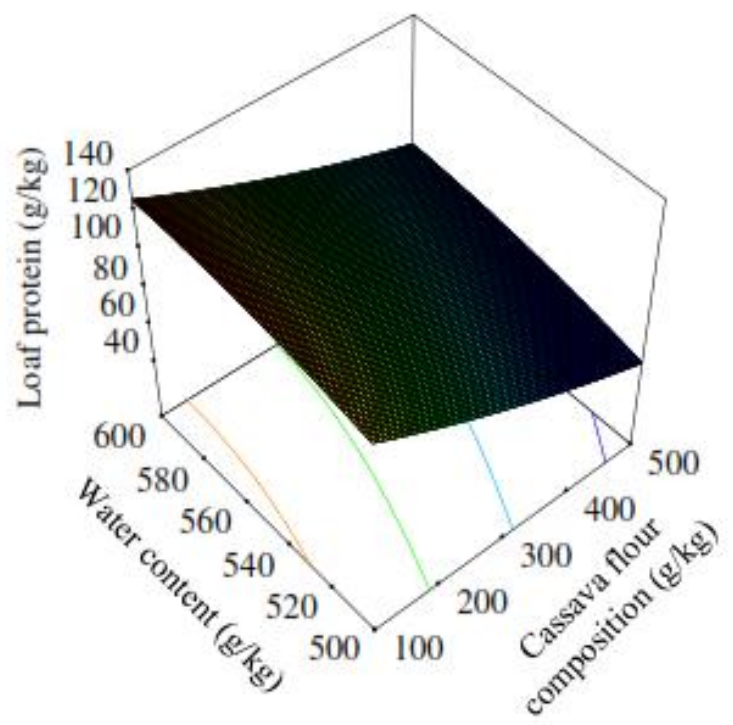

(a)
Olurin, T.O., Dudu, O.E., Olaniyan, A.M. and Ogunmoyela, O.A.B.

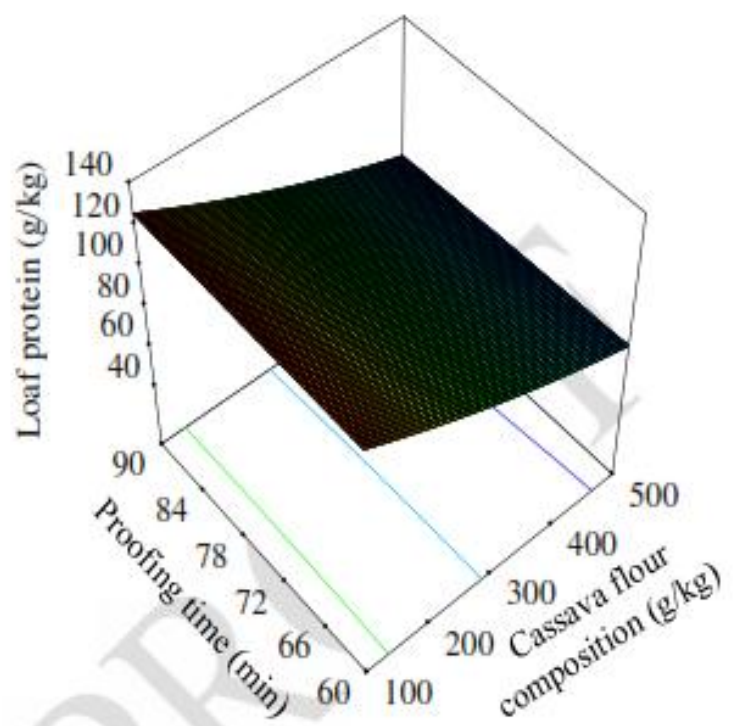

(b)

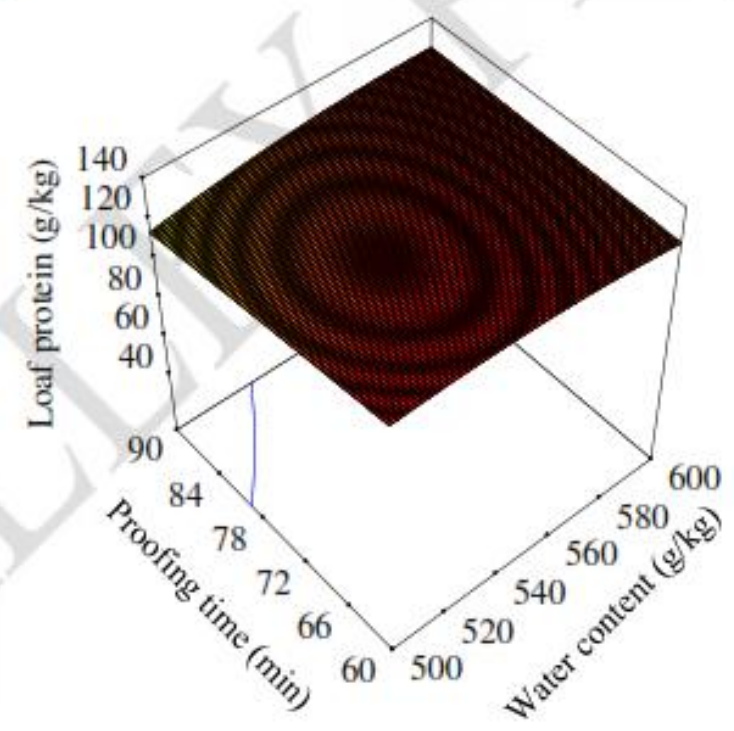

(c)

Fig. 3 Response surface plots of loaf protein as a function of different experimental conditions

Journal of the Faculty of Agriculture and Veterinary Medicine, Imo State University Owerri website: www ajol.info; Attribution:Non- commercial CC BY-NC 